\title{
Pelatihan Pengolahan Sampah Organik Menjadi Kompos di Desa Bon Jeruk Kecamatan Jonggat Kabupaten Lombok Tengah
}

\author{
Humairo Saidah $^{1}$, Desi Widianty ${ }^{2}$, Aryani Rofaida ${ }^{2}$, I.A.O.S.Sideman ${ }^{4}$ Rohani $^{5}$, \\ Lalu Adi Permadi ${ }^{6}$
}

\author{
${ }^{1}$ Jurusan Sipil Fakultas Teknik Universitas Mataram, Mataram, Indonesia, ${ }^{2,3,4,5}$ Jurusan \\ Sipil Fakultas Teknik Universitas Mataram, Mataram, Indonesia, ${ }^{6}$ Jurusan Manajemen \\ Fakultas Ekonomi Universitas Mataram, Mataram, Indonesia.
}

\section{Alamat korespondensi : h.saidah@unram.ac.id}

\begin{abstract}
ABSTRAK
Desa Bonjeruk adalah sebagai Desa Wisata Budaya dengan bekal kesejarahannya. Selain memiliki tempat yang bersejarah, wisata desa Bonjeruk juga mengusung konsep ecotourism yang menawarkan keaslian kehidupan desa lengkap dengan penghidupan masyarakatnya sebagai petani. Namun petani setempat belum memiliki pengetahuan untuk mengelola sampah pertaniannya. Salah satu teknik memanfaatkan limbah menjadi pupuk adalah menjadikannya sebagai pupuk kompos untuk menekan pemakaian pupuk anorganik yang dalam jangka panjang residu dan limbahnya dapat merusak lingkungan sekaligus menyelesaikan permasalahan sampah. Kegiatan dilaksanakan dalam bentuk penyuluhan, pelatihan dan pendampingan. Penyuluhan dimaksudkan untuk berbagi pengetahuan tentang isu lingkungan terkait masalah sampah sekaligus ajakan untuk berperan aktif dalam gerakan penyelamatan lingkungan. Kegiatan penyuluhan diperkuat dengan pemberian pelatihan tentang cara mengolah sampah organik menjadi pupuk kompos. Selain pelatihan pembuatan kompos, kegiatan juga ditujukan untuk menginisiasi pembentukan bank sampah masyarakat desa Bonjeruk sebagai upaya rintisan menuju desa Proklim, sebuah program peningkatan kapasitas masyarakat untuk mitigasi dan adaptasi terhadap perubahan iklim dari Kementerian Lingkungan Hidup dan Kehutanan. Kegiatan ini telah terlaksana dan mendapat sambutan antusias dari warga. Kini warga makin menyadari nilai ekonomis dari sampah yang mereka hasilkan dengan mampu membuat sendiri pupuk kompos dari limbah organik.
\end{abstract}

Keywords : Sampah Organik, Kompos, Desa Bonjeruk

\section{PENDAHULUAN}

Desa Bonjeruk adalah desa yang kini berbenah untuk kesuksesan program desa wisata budaya yang telah dicanangkan. Pariwisata Inti Rakyat (PIR) dalam Hadiwijoyo (2012:68) mendefinisikan desa wisata adalah suatu kawasan pedesaan yang menawarkan keaslian suasana perdesaan yang mencerminkan kehidupan sosial ekonomi, sosial budaya, adat istiadat, keseharian, memiliki arsitektur bangunan dan struktur tata ruang desa yang khas, atau kegiatan ekonomi yang unik dan menarik serta berpotensi untuk dikembangkan. Desa Bonjeruk memiliki asset yang sangat bernilai dan signifikan untuk ditawarkan sebagai desa wisata budaya. Selain pemandangan desa yang indah, desa ini juga menawarkan udara yang sejuk karena berada pada ketinggian +690 dpl serta komoditi perkebunan yang sangat menjanjikan diantaranya adalah kopi, durian, dan lain-lain. Di desa ini terdapat bangunan kuno bekas Distrik Jonggat pada zaman Belanda yang masih berdiri kokoh dan terawat baik hingga sekarang, dan masjid tua Nuna Umas yang berdiri tahun 1800an. Selain itu desa ini juga memiliki potensi agrowisata serta spot wisata alam lain seperti air terjun yang sangat menarik (Laporan KKN, 2019). Sehingga program desa wisata ini sangat layak diperjuangkan keberhasilannya. 
Sebagai daerah wisata yang menawarkan wisata budaya berkonsep ecotourism, maka paket keindahan alam beserta keaslian kehidupan masyarakatnya menjadi satu kesatuan yang ditawarkan. Dalam seminggu setidaknya ada 3-4 kali kunjungan yang masing-masing membawa 10 orang wisatawan dari luar menuju desa ini (Tempo.co., 2019). Untuk itu maka diperlukan penyadaran masyarakat akan pentingnya lingkungan yang bersih dan nyaman yang mendukung keberhasilan program pariwisata. Kegiatan gotong royong sebenarnya telah dilakukan seminggu sekali namun hasil yang dicapai belum maksimal karena tingkat kesadaran masyarakat yang rendah serta pengetahuan yang minim tentang cara pengolahan sampah.

Salah satu cara pengendalian sampah adalah dengan mengolah kembali berbagai sampah tersebut sesuai jenisnya. Sampah organik dari hasil petanian dapat dijadikan pupuk kompos, dan sampah anorganik (terutama plastik) dapat diubah menjadi berbagai barang kerajinan yang mempunyai nilai jual yang tinggi misalnya hiasan rumah, tas, bunga, bros, dan berbagai souvenir lain. Maka untuk tujuan pengendalian sampah sekaligus upaya peningkatan kesejahteraan masyarakat lewat kegiatan kreatif, maka tim merasa perlu memberikan berbagai pengetahuan tentang cara pengolahan sampah menjadi barang yang berguna dan bernilai jual.

Kegiatan pelatihan difokuskan pada penanganan sampah organik untuk diolah menjadi kompos dengan metode Takakura. Namun karena beberapa pertimbangan yaitu lokasi pengabdian berada di desa yang memiliki sampah organik berlimpah dan tidak ada masalah dengan lahan untuk pembuatan kompos, maka pelatihan juga memberikan materi tentang teknik pengomposan dengan cara biasa. Pengolahan kompos dengan metode Takakura dipilih karena kapasitasnya cocok untuk diaplikasikan pada skala rumah tangga, menggunakan alat dan bahan yang mudah didapatkan, selain itu juga bersih dan tidak berbau sehingga tidak mengganggu kenyamanan. Namun metode ini memiliki kapasitas yang terbatas dalam mengolah sampah karena menggunakan keranjang sebagai tempat pengomposan.

\section{METODE KEGIATAN}

Kegiatan pengabdian masyarakat ini disampaikan dalam tiga tahap, dimana tahap pertama adalah penyuluhan, yang bertujuan untuk menyebarkan isu-isu terkait sampah dan permasalahannya serta menggugah kesadaran masyarakat untuk mau berkontribusi menyelesaikan permasalahan sampah. Penyuluhan dilakukan melalui kelompok masyarakat yang ada di lingkungan pemerintahan desa Bonjeruk. Pembentukan kelompok ini bertujuan untuk memudahkan koordinasi di tingkat bawah serta sebagai sarana berkumpul dan bertukar pikiran sesama warga dalam proses kreatif mengolah sampah. Kegiatan ini dilaksanakan di sekretariat PokDarWis Putra Jonggat.

Kegiatan kedua adalah Pelatihan pembuatan kompos dengan metode Takakura dan metode biasa. Pelaksanaan pelatihan dilaksanakan di Sekretariat PokDarWis Putra Jonggat dengan mengundang segenap elemen masyarakat utamanya petani atau pelaku pertanian ataupun ibu-ibu maupun masyarakat umum.

Kegiatan ketiga adalah pendampingan. Kegiatan ini adalah follow up dari kegiatan pelatihan yang telah dijalankan pada tahap sebelumnya. Pola pendampingan yang diberikan adalah dengan memberikan layanan konsultansi selama pembuatan pupuk. Pendampingan diperlukan selain untuk sarana konsultansi juga merupakan bentuk kontrol dari tim dalam memantau kreativitas warga dalam mengolah sampah sekaligus mengukur keberhasilan kegiatan. 


\section{HASIL DAN PEMBAHASAN}

Kegiatan pengabdian ini dilaksanakan dalam tiga tahap yaitu penyuluhan, pelatihan dan pendampingan. Pada awalnya kegiatan pengabdian masyarakat ini dimulai dari permintaan mahasiswa KKN yang memiliki program pemanfaatan sampah yang diawali dengan keprihatinan akan rendahnya kesadaran masyarakat akan kebersihan lingkungan. Sementara desa Bonjeruk sedang menggalakkan upaya mengangkat pamornya menjadi desa wisata budaya. Maka kebersihan dan kenyamanan mutlak diperlukan untuk menunjang keberhasilan desa wisata. Melihat kebutuhan tersebut maka dilakukanlah beberapa langkah persiapan kegiatan pengabdian kepada Masyarakat dengan tema memanfaatkan sampah menjadi barang berguna dan bernilai jual.

Kegiatan pelatihan pemanfaatan sampah ini diawali dengan penyuluhan. Penyuluhan dilakukan dalam dua kali pertemuan. Pertemuan pertama dilakukan pada bulan Februari 2020 sebelum Covid-19 meluas sehingga Pemerintah membatasi kegiatan masyarakat di luar rumah dan bahkan melarang masyarakat untuk berkumpul, sehingga penyuluhan pertama berjalan lancar dan tidak menemui hambatan. Pertemuan pertama Tim memberi pelatihan pemanfaatan kembali sampah plastik menjadi berbagai produk handycraf yang berguna seperti bunga, bros, gantungan kunci, dan lain-lain.

Pertemuan kedua adalah pemberian pelatihan pengolahan sampah organik menjadi pupuk kompos. Pelatihan kedua ini bertujuan untuk melengkapi pengetahuan masyarakat dalam pengolahan sampah organik sebagai salah satu bahan buangan yang jumlahnya melimpah. Ketrampilan membuat pupuk kompos ini jika ditangani dengan serius, dipasarkan dan dimenej dengan baik maka dapat menjadikan peluang yang sangat potensial meningkatkan pendapatan masyarakat.

Kegiatan penyuluhan dilakukan pada bulan pertama kegiatan dengan melibatkan seluruh anggota kelompok. Kegiatan ini dilaksanakan di sekretariat PokDarWis Putra Jonggat yang ada di Desa Bonjeruk Kecamatan Jonggat. Kegiatan ini memberi penyuluhan dengan mengangkat isu-isu lingkungan dan kerusakan lingkungan akibat sampah terutama sampah plastik.

Tingginya penggunaan plastik di segala sektor telah membuat masalah sampah di berbagai negara, termasuk Indonesia. Karena bahan plastik membutuhkan waktu ratusan tahun untuk bisa terurai. Sampah plastik dalam jumlah besar akan menjadi masalah bagi lingkungan. Dengan kebiasaan sebagian masyarakat yang membuang sampah di sungai, maka akan menghambat aliran sungai hingga menyebabkan banjir, mengotori pantai, mencemari laut hingga mengakibatkan banyak hewan laut mati dengan perut berisi sampah plastik.

Masalah tersebut dapat direduksi dengan menerapkan gaya hidup tanpa sampah (zero waste) dengan 3R yaitu Reduce (mengurangi), Reuse (menggunakan kembali) dan Recycle (mengolah kembali), dan melakukan berbagai Langkah kongkrit untuk mengurangi pemakaian plastik dan menggantinya dengan bahan lain yang lebih mudah terurai.

Selain sosialisasi dampak pembuangan sampah plastik yang membebani lingkungan, penyuluhan ini juga memberikan pelatihan kepada ibu-ibu PKK yang hadir untuk memanfaatkan sampah plastiknya menjadi berbagai souvenir dan kerajinan tangan yang indah dan bernilai jual. Kegiatan ini dilaksanakan pada bulan Februari sebelum merebak kasus Covid-19. Berikut ini foto-foto kegiatan yang dilakukan pada bulan pertama pengabdian bekerja sama dengan mahasiswa KKN tematik di desa Bonjeruk yang dilaksanakan pada bulan Februari tahun 2020. 


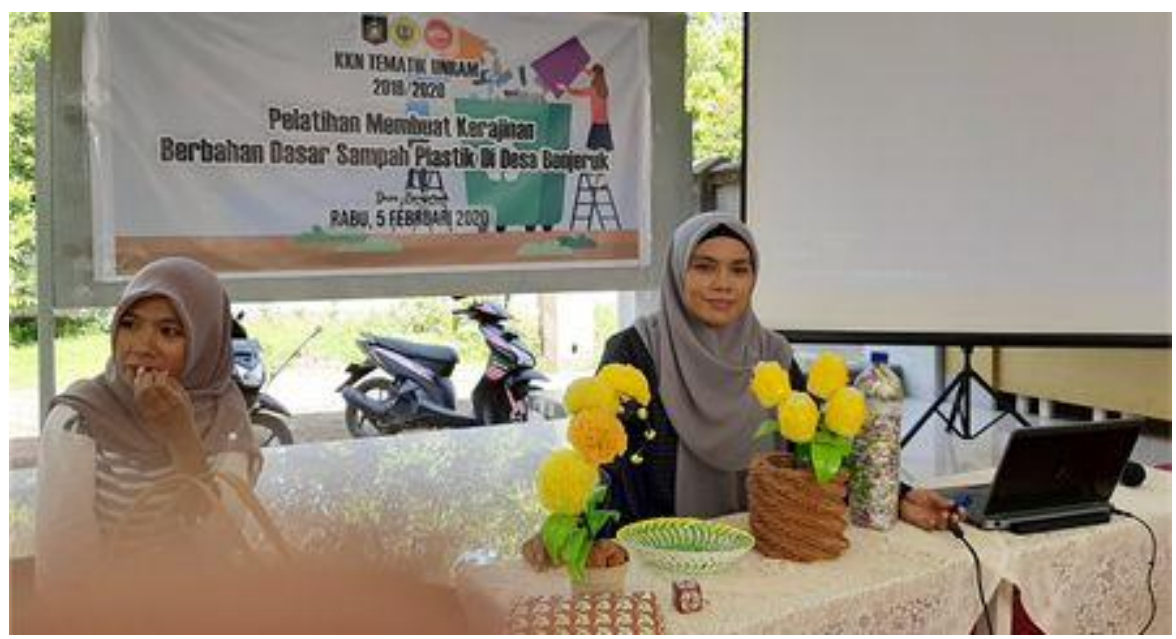

Gambar 1. Penyuluhan sampah plastik

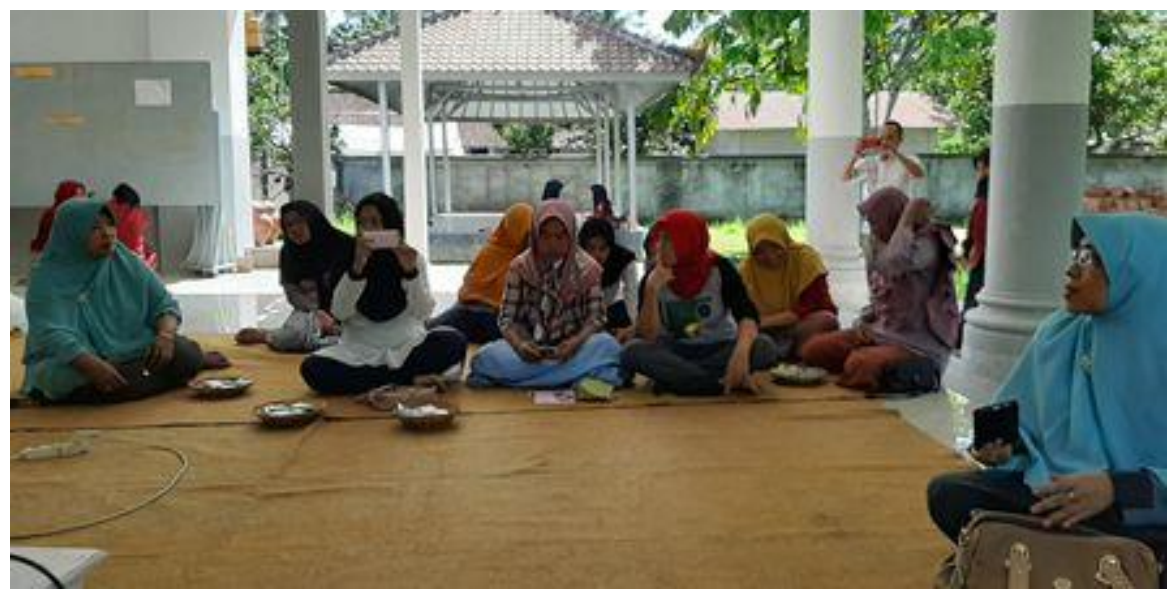

Gambar 2. Peserta penyuluhan pengolahan sampah plastik

Pelatihan kedua adalah Pelatihan dalam penanganan sampah organik menjadi pupuk kompos dengan metode Takakura maupun metode biasa. Pelaksanaan pelatihan dilaksanakan di Sekretariat PokDarWis Putra Jonggat dengan mengundang berbagai elemen masyarakat utamanya pelaku pertanian, karang taruna, maupun masyarakat umum. Pelatihan ini dilaksanakan pada era new normal yaitu pada bulan Oktober 2020 di Dusun Peresak Desa Bonjeruk Kabupaten Jonggat. Diawali dengan pembagian masker untuk peserta pelatihan dan himbauan pola hidup bersih sehat serta menjalankan protokol kesehatan secara konsisten. Berikut foto-foto kegiatan pelatihan pembuatan kompos. 


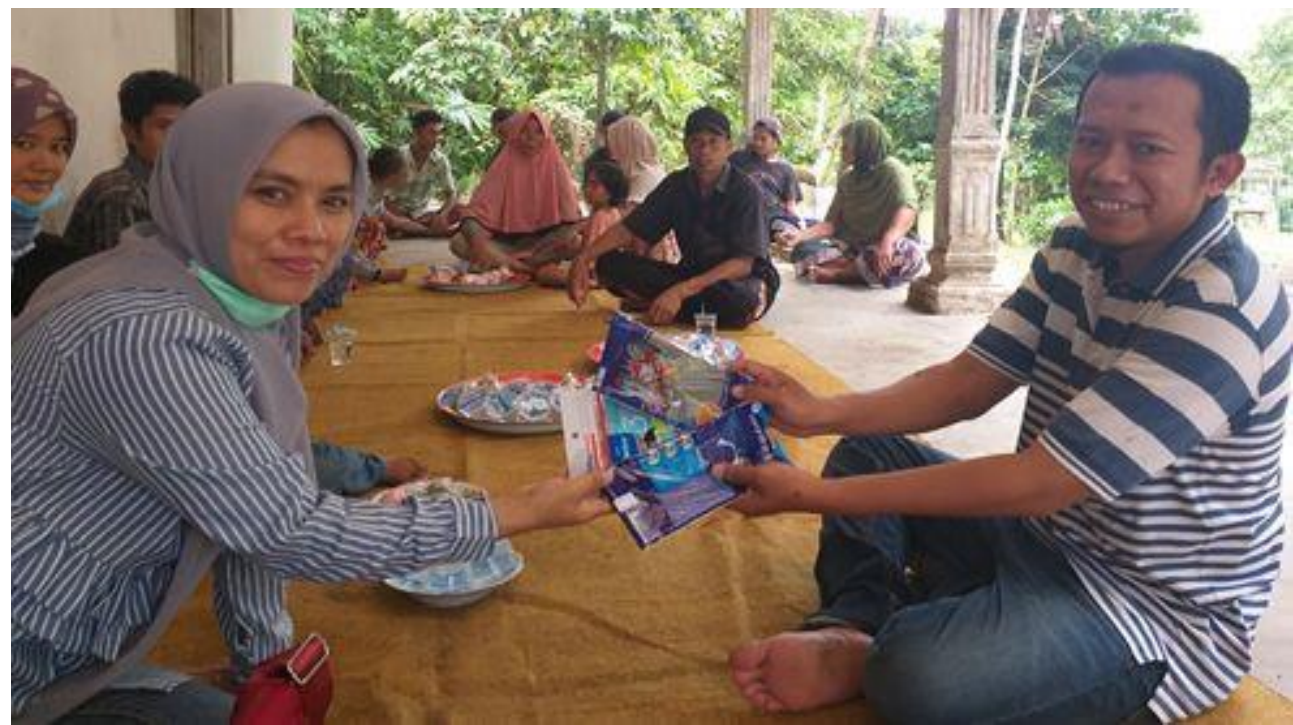

Gambar 3. Penyerahan masker sebagai bagian dari kampanye protokol Kesehatan

Pada saat pelatihan, Tim menjelasan tentang cara pengomposan bahan organik dengan menggunakan bantuan dekomposer EM4 yang dapat dibeli secara mudah di toko pertanian atau menggunakan dekomposer buatan sendiri yang dikenal dengan istilah MOL (Mikro Organiasme Lokal) yang terbuat dari bahan alami yang ada di sekitar rumah misalnya jamur pada nasi basi ataupun menggunakan terasi. Dalam menjelaskan masalah ini masyarakat tampak antusias mengikuti penjelasan yang disampaikan oleh Tim yang ditunjukkan dengan keaktifan mereka dalam bertanya dan memberi umpan balik kepada Tim

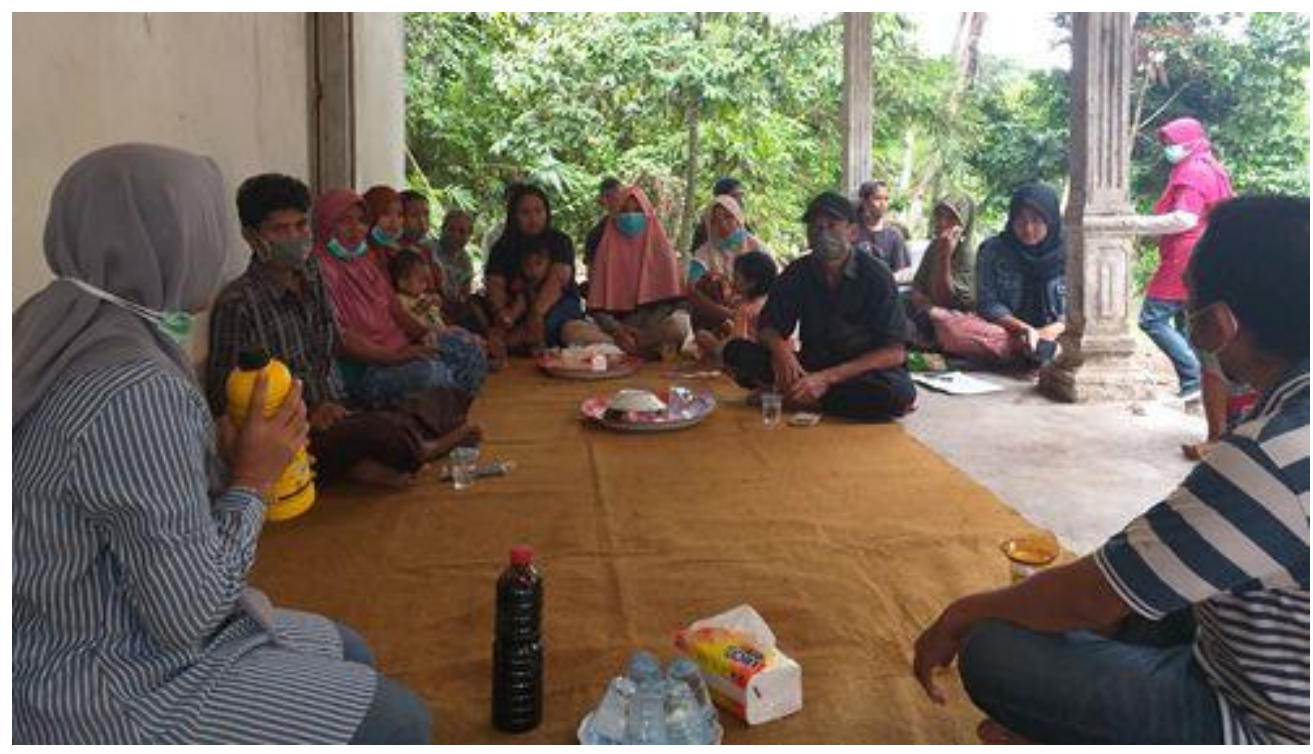

Gambar 4. Penjelasan tentang bahan untuk pembuatan kompos 


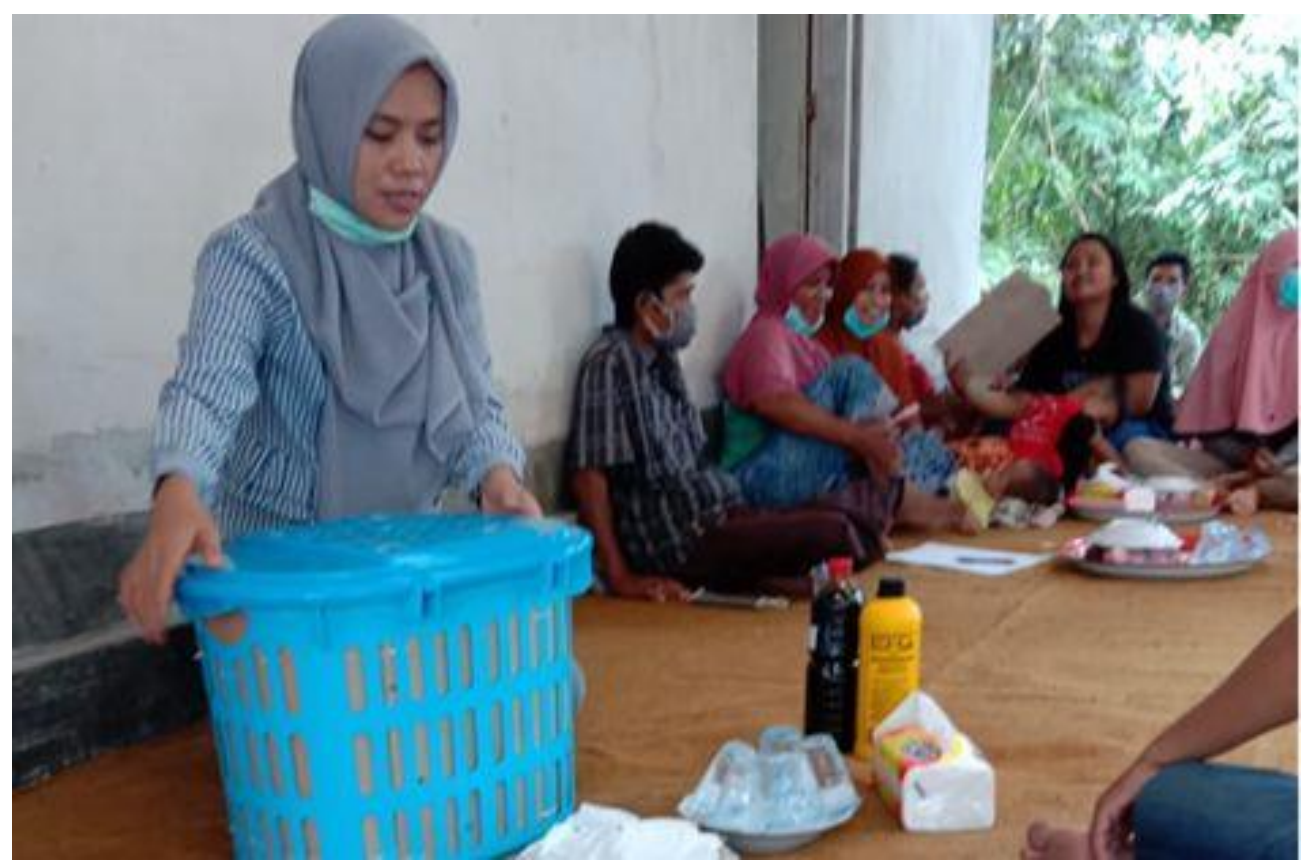

Gambar 5. Penjelasan tentang cara pembuatan kompos metode Takakura

Penjelasan tentang Teknik pengomposan dengan metode Takakura dirasa cukup sulit untuk diterapkan oleh warga desa mengingat Teknik ini membutuhkan modal berupa keranjang yang harganya cukup mahal. Dalam menyikapi pandangan masyarakat ini Tim memberikan pandangan berupa alternatif barang lain pengganti keranjang yang juga dapat digunakan, misal karung beras, keranjang dari bambu, dan lain-lain. Pada tahap ini masyarakat juga meminta Tim untuk memperlihatkan secara langsung Teknik pengomposan menggunakan sampah kebun yang sangat berlimpah. Sampah kebun ini selama ini hanya dibakar dan atau dibuang ke sungai oleh masyarakat sebelum mengetahui teknik pengolahan sampah dengan cara dikomposkan.

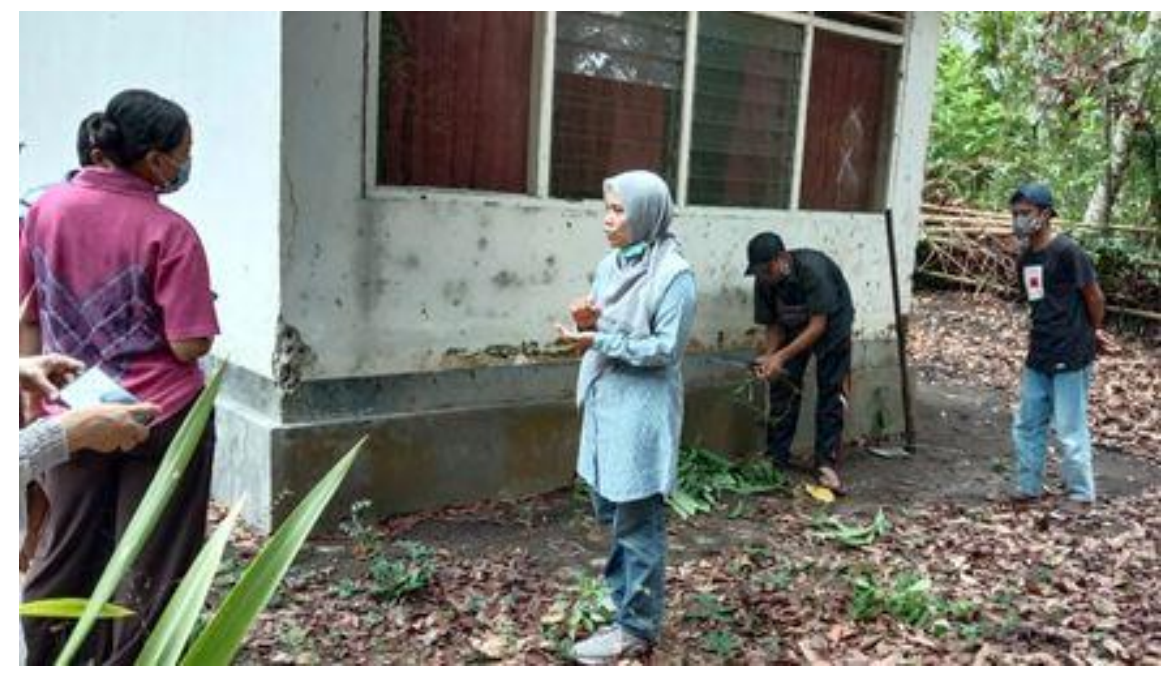

Gambar 6. Praktek membuat kompos dengan bahan limbah kebun 
Langkah terakhir dalam rangkaian kegiatan ini adalah pendampingan. Tampaknya masyarakat sangat tertarik dengan pengetahuan baru cara pengomposan sampah, yang diperlihatkan dengan banyaknya masyarakat yang mempertanyakan ulang berbagai hal yang belum mereka fahami tentang pengomposan memalui chat WA. Masyarakat menanyakan dimana membeli bahan-bahan yang diperlukan missal EM4 dan dengan penuh semangat mengumpulkan sampah dicampur dengan kotoran ayam dari peternakan yang ada di lingkungan mereka yang selama ini kotorannya menumpuk dan belum termanfaatkan.

Setelah satu bulan berlalu dari kegiatan pelatihan, masyarakat masih saja mengkonsultasikan perihal kompos yang mereka buat. Meski kompos belum sepenuhnya matang, namun pengenalan proses pembuatan kompos ini telah membuka wawasan masyarakat desa BonJeruk untuk dapat memanfaatkan sampah organik di sekitar mereka menjadi sesuatu yang bermanfaat dan bernilai jual. Apalagi di era new normal ini kebutuhan akan pangan organik menjadi gaya hidup baru masyarakat dengan tingginya kegiatan urban farming baik di desa maupun di kota.

\section{KESIMPULAN DAN SARAN}

Beberapa kesimpulan yang dapat ditarik dari kegiatan Pengabdian kepada Masyarakat ini adalah :

1. Perlunya berbagai pihak utamanya Perguruan Tinggi untuk aktif menyebarluaskan berbagai informasi kepada masyarakat, karena terkadang informasi sederhana pun belum terjangkau oleh masyarakat di lapisan bawah.

2. Pengetahuan pembuatan pupuk kompos ini telah membuka wawasan masyarakan desa Bonjeruk untuk memanfaatkan sampah mereka dengan cara yang benar sehingga sampah pun dapat berharga dan bernilai jual.

Saran untuk kegiatan selanjutnya adalah perlunya pendampingan masyarakat dalam membuka akses pasar dalam memasarkan produk yang mereka hasilkan, misalnya pupuk kompos ataupun hasil pertanian yang yang dihasilkan dari bertani organik.

\section{UCAPAN TERIMA KASIH}

Penulis mengucapkan terima kasih kepada Universitas Mataram yang telah mendanai kegiatan Pengabdian kepada Masyarakat ini.

\section{DAFTAR PUSTAKA}

Hadiwijoyo, S.S. 2012. Perencanaan Pariwisata Perdesaan Berbasis Masyarakat. Graha Ilmu. Yogyakarta.

Tempo.co, 2019, "Pelesiran ke Desa Bonjeruk: Sawah, Sejarah, dan Kopi Enak" https://travel.tempo.co/read/1280876/pelesiran-ke-desa-bonjeruk-sawah-sejarah-dankopi-enak, akses 10 November 2020 